\title{
INVESTIGATION OF THE CHARACTERISTICS OF FLOW OVER SPILLWAYS
}

Gamal M. Abdel Aal, Mohamed A. Nassar, Amany A. Habib

\begin{abstract}
To prevent severe scouring of waterway bed and failure of downstream spillway structures as a result of h! being swept out of the basin. Experimental studies investigating the flow characteristics for different spillw carried out. The measurements are focusing on recoding of water surface at different sections. The experir program explores the effect of different baffle blocks composition on the spillway face. In addition, it inves effects of the strips walls' relative and the end sill's characteristics. The experiments indicate that the case blocks over sloped spillway gives the smallest flow depth ratio compared to the other baffle blocks compos found that the stepped spillway structure with end sill is more efficient than the other spillways. The deriv equation for relative energy loss gives a good agreement with the experimental data. Prediction equations developed using the multiple linear regression to model the relative energy loss through the spillway struc acceptable agreement was obtained between the predicted and the measured values. A model of the relati loss is built using Genetic Programming (GP). Many trails were done to reach the optimum model. It was $f_{1}$ GP model results are more accurate than that obtained by the regression technique. Finally, the conclusior study can be recommended in the design procedure and practical applications.
\end{abstract}

